\title{
Screening and cervical cancer cure: population based cohort study
}

\author{
(c) $\frac{(1) \&(8)}{\mathrm{EY}}$ OPEN ACCESS
}

\author{
Bengt Andrae senior consultant ${ }^{12}$, Therese M-L Andersson doctoral student ${ }^{2}$, Paul C Lambert \\ reader $^{23}$, Levent Kemetli statistician ${ }^{4}$, Lena Silfverdal senior consultant ${ }^{5}$, Björn Strander senior \\ consultant $^{6}$, Walter Ryd associate professor ${ }^{7}$, Joakim Dillner professor ${ }^{28}$, Sven Törnberg associate \\ professor $^{4}$, Pär Sparén professor ${ }^{2}$
}

${ }^{1}$ Centre for Research and Development, Uppsala University/County Council of Gävleborg S-80188 Gävle, Sweden; ${ }^{2}$ Department of Medical Epidemiology and Biostatistics, Karolinska Institutet, Stockholm, Sweden; ${ }^{3}$ Department of Health Sciences, Centre for Biostatistics and Genetic Epidemiology, University of Leicester, Leicester, UK; ${ }^{4}$ Department of Cancer Screening, Karolinska University Hospital, Stockholm, Sweden; ${ }^{5}$ Department of Obstetrics and Gynaecology, Umeå University Hospital, Umeå, Sweden; ${ }^{6}$ Department of Obstetrics and Gynaecology, Institute of Clinical Sciences, Sahlgrenska Academy, Gothenburg University, Sweden; ${ }^{7}$ Department of Pathology and Clinical Cytology, Sahlgrenska University Hospital, Gothenburg, Sweden; ${ }^{8}$ Department of Laboratory Medicine, Karolinska Institutet, Stockholm, Sweden

\begin{abstract}
Objective To determine whether detection of invasive cervical cancer by screening results in better prognosis or merely increases the lead time until death.

Design Nationwide population based cohort study. Setting Sweden.

Participants All 1230 women with cervical cancer diagnosed during 1999-2001 in Sweden prospectively followed up for an average of 8.5 years.

Main outcome measures Cure proportions and five year relative survival ratios, stratified by screening history, mode of detection, age, histopathological type, and FIGO (International Federation of Gynecology and Obstetrics) stage.

Results In the screening ages, the cure proportion for women with screen detected invasive cancer was $92 \%$ (95\% confidence interval $75 \%$ to $98 \%$ ) and for symptomatic women was $66 \%$ (62\% to $70 \%$ ), a statistically significant difference in cure of $26 \%$ (16\% to $36 \%$ ). Among symptomatic women, the cure proportion was significantly higher for those who had been screened according to recommendations (interval cancers) than among those overdue for screening: difference in cure $14 \%$ ( $95 \%$ confidence interval $6 \%$ to $23 \%$ ). Cure proportions were similar for all histopathological types except small cell carcinomas and were closely related to FIGO stage. A significantly higher cure proportion for screen detected cancers remained after adjustment for stage at diagnosis (difference 15\%, 7\% to $22 \%$ ).
\end{abstract}

Conclusions Screening is associated with improved cure of cervical cancer. Confounding cannot be ruled out, but the effect was not attributable to lead time bias and was larger than what is reflected by down-staging. Evaluations of screening programmes should consider the assessment of cure proportions.

\section{Introduction}

The rationale of cervical screening is to reduce the incidence of cancer by the detection and treatment of precursors. ${ }^{12} \mathrm{~A}$ secondary aim is the early detection of invasive disease, which might improve the prognosis thereby also reducing mortality from the disease. Prognosis may depend on age, FIGO (International Federation of Gynecology and Obstetrics) stage, histopathological type, screening history, and mode of detection. ${ }^{3}$ Thus cancers may be detected on the basis of either an abnormal screening test result or symptoms, and the women may also have been screened previously according to recommendations or not. The Swedish cervical screening programme carried out a nationwide audit of the screening history of all cases in the country and found that in addition to preventing cervical cancer, regular screening also detected invasive cervical cancers at earlier stages. In the nationwide Swedish audit ${ }^{1}$ around $50 \%$ of women who were not screened according to recommendations were detected at FIGO stage II or higher, whereas among women participating in the screening programme most were at stages IA or IB (30\% and 52\%, respectively). For screen detected cancers the drift towards detection at early stages was even more apparent (47\% of cancers were detected at stage IA and $46 \%$ at stage IB).

However, the early detection of asymptomatic cancers is intuitively but not necessarily beneficial, ${ }^{4-6}$ as lead time and length biases can distort the apparent benefit of screening 
programmes. ${ }^{78}$ Randomised controlled trials are not feasible for the evaluation of established cervical screening programmes, which is why the only alternative is well designed observational studies. ${ }^{9}$ In an extension of the nationwide Swedish audit, we investigated if, and to what extent, participation in cervical screening according to guidelines and/or screen detection of invasive cancer is reflected in improved cure of disease by utilising recently developed statistical methods for estimating the cured proportion of women with cervical cancer. ${ }^{10}{ }^{11}$

\section{Methods}

The organised Swedish cervical screening programme issues invitations three years after the latest smear test for women aged 23-50 and every five years for women aged 51-60. Invitations to screening are issued by regional offices to all women in the population register who have not been screened according to recommendations. ${ }^{12-14}$ The cytology databases used to assess screening history include all smear tests taken, not just the organised ones. The design of the nationwide audit of cervical screening in Sweden has been described previously. ${ }^{1}$ In the present prospective cohort study we linked all women with cervical cancer in Sweden diagnosed during 1999-2001 to the national Swedish causes of death register, with follow-up to 31 December 2006. Death from cervical cancer or unspecified uterine cancer was considered cause specific mortality. ${ }^{15}$ To ascertain the date of death from any cause until 31 December 2008, we linked all cases to the Swedish population register. We analysed separately those women with cancer diagnosed at screening ages 23-65 (including one woman with a diagnosis at age 21) and those with a diagnosis more than five years beyond the last invitation to screening ( $\geq 66$ years). Screen detected cancers were defined as those in women with an abnormal smear test result recorded 1-6 months before diagnosis. We classified the remaining women as symptomatic. ${ }^{1}$ Smear tests taken less than one month before diagnosis were not considered as they might be part of the diagnostic process of a symptomatic invasive cancer (fig $1 \Downarrow$ ).

We divided the women with symptomatic cancer into symptomatic interval cases if the cancer was diagnosed more than six months after the smear test but within the recommended screening interval of 3.5 years in women under the age of 54, or within 5.5 years before diagnosis in women over that age. Symptomatic overdue, or not screened, comprised women whose screening test was more than half a year overdue according to screening guidelines, and included women without any previous smear test. We divided the women with screen detected cancer, having a smear test done 1-6 months before diagnosis, into women who also had a smear test taken within the preceding recommended interval (screen detected interval cancers) and those whose screening was overdue or who had no recorded smear test (screen detected, overdue or not screened).

FIGO stage is considered a good predictor of survival. ${ }^{16-18}$ The classification used in this study-IA, microinvasive; IB,

localised; and II or higher, advanced —reflect distinct levels of treatment, consequences for fertility, complications, and costs.

\section{Statistical analysis}

We calculated relative survival ratios as the overall (all cause) survival in the cohort over the expected survival in the general female population, comparable with the women diagnosed as having cancer according to age and calendar year. Relative survival estimates mortality, associated with a diagnosis of a particular disease, without the need for information on cause of death. ${ }^{19}$
Statistical cure is defined as the point where the relative survival curve reaches a plateau, and this occurs when the women who are still alive no longer experience any excess mortality compared with the general female population. These women are considered statistically cured as they experience the same mortality as women of the same age without cancer. The level at which the relative survival curve reaches a plateau is named the cure proportion..$^{10}$ The concept of "statistical cure" applies at a grouped level and is distinct from "medical cure" at an individual level, as it is difficult to determine with any certainty that someone has been medically cured.

The statistical model for cure used in this paper-the mixture cure mode $l^{10}$-assumes that a proportion of patients will be cured (experience the same mortality as the general population) whereas the remaining (1-proportion) of patients will continue to experience excess mortality compared with the general population. The group who continue to experience excess mortality are considered to be uncured or those bound to die of the disease under study. For the models in this article we assume that the survival times of those who are uncured have a Weibull distribution. We used a logit link to model the cure proportion, which gives parameter estimates that can be interpreted as odds ratios of cure, with values greater than 1 indicating a higher odds of cure and values less than 1 indicating a lower odds of cure. In addition we calculated the difference, with $95 \%$ confidence intervals, in the cure proportions.

For all cure models we applied either included terms for mode of detection (screen detected versus symptomatic) or attendance at screening (screened within recommended interval versus screening overdue or no smear test). We then fitted separate models, with the following covariates also included: FIGO stages (IA, IB, II, or III or higher) and histopathology (squamous cell versus adenocarcinoma). From the model we excluded those women with adenosquamous, small cell, neuroendocrine, or undifferentiated carcinomas owing to small numbers. We restricted the analysis to the younger age group when adding stage and histopathology, because the models did not give a good fit for the older age group - that is, the relative survival curves did not appear to reach a plateau. To formally assess whether a difference existed in cure proportion between women with screen detected cancer and those with symptomatic cancer, we estimated odds ratios of cure with $95 \%$ confidence intervals, where the women with screen detected cancer served as the reference group, with an odds ratio of 1 . We then introduced FIGO stage into the model to test the hypothesis that clinical stage at detection explains any difference in cure proportion between women with screen detected cancer and those with symptomatic cancers. For univariate models we report the difference in the cure proportion with standard errors, calculated using the delta method. For the models incorporating FIGO stage, we computed stage standardised differences in the cure proportion by assuming that the stage distribution in the each of the two groups was the same as that of the whole study population. We used the same approach to estimate the difference in cure proportions between women screened within the recommended interval compared with those whose screening was overdue or who had no smear test, and the hypothesis that clinical stage at detection explains any difference in cure.

When presenting estimates of the cure proportion, we categorise FIGO stage in three levels (IA, IB, and II or higher), because the estimates for further subdivisions into stages II and III or higher were unreliable, and consequently did not add any further information.

Estimation of the model variables was obtained with maximum likelihood using individual level data. ${ }^{11}{ }^{20} \mathrm{We}$ modelled both 
Weibull parameters $\left(\lambda\right.$ and $\gamma$ ). (See Lambert et $\mathrm{al}^{11}$ for further discussion of the interpretation of estimates from cure models.) The strsmix command in Stata was used to fit models. ${ }^{21}$

\section{Results}

At least seven years of potential follow-up were available from diagnosis of cervical cancer for all the women. Five years after diagnosis, 440 out of the 1230 women had died. Among them 373 had a recorded death from cervical cancer. Thirty one women died from other cancers, and 36 died of diagnoses not related to cancer.

The five year relative survival for women at screening ages with screen detected cancers was 95\% (95\% confidence interval 92\% to $97 \%$ ), whereas for women with symptomatic cancers it was $69 \%$ ( $65 \%$ to $73 \%$; table $1 \Downarrow$ ). The corresponding cure proportions were $92 \%$ (75\% to $98 \%$ ) and $66 \%$ (62\% to $70 \%$ ), with an estimated difference in cure of $26 \%$ (15\% to $36 \%$ ).

However, the cure proportion for women with symptomatic cancers presenting within the recommended screening interval was $74 \%$ (68\% to $79 \%)$, whereas for symptomatic cancers in women overdue for screening it was $60 \%$ (53\% to 66\%), with a difference in cure of $14 \%$ (6\% to 23\%). Differences in cure proportions between different FIGO stages were large both for women with screen detected cancers and for women with symptomatic cancers (table 1). In FIGO stage IA the difference between screen detected and symptomatic cancers was 4\% (3\% to $7 \%$ ), whereas in stages IB and II or higher the difference increased to $16 \%$ ( $8 \%$ to $23 \%$ ) and $29 \%$ (13\% to $45 \%$ ), respectively (table 1). For screen detected cancers evidence of any substantial difference in cure was lacking between squamous cell carcinoma and adenocarcinoma (cure proportions 93\%) and this was also the case for symptomatic cancers (cure proportions $67 \%$ and $66 \%$, respectively; table 1). For both of the major histological subtypes, however, differences in cure were apparent between women with screen detected cancers and women with symptomatic cancers (table 1). Deaths related to adenosquamous, small cell, neuroendocrine, or undifferentiated carcinomas were too few to reliably calculate cure rates, and no deaths occurred among women with these histological subtypes for screen detected cancers.

Table $2 \Downarrow$ presents odds ratios and differences of cure by mode of detection and screening history. For odds ratios, the women with interval cancers served as the reference group, with an odds ratio of 1 . The difference in cure between the women with symptomatic cancers and those with screen detected cancers was $26 \%$ (95\% confidence interval $15 \%$ to $36 \%$; table 2 ). When FIGO stage was introduced into the model, the difference in cure between the groups decreased to $15 \%$ ( $7 \%$ to $22 \%$ ).

The cure proportion for women who had a smear test within the recommended screening interval at ages 23 to 65 was $11 \%$ (95\% confidence interval $5 \%$ to $18 \%$ ) higher than for women who were overdue or who had never had a smear test (table $3 \Downarrow$ ). Women with a normal smear test result had a non-significantly lower cure proportion (difference $8 \%, 95 \%$ confidence interval $-0.4 \%$ to $17 \%$ ) than women with an abnormal smear test result. The patterns of lower cure proportions with increasing FIGO stage was seen for both interval and overdue cases, although the $95 \%$ confidence intervals for the stage specific differences all included zero (table 3 ). The evidence for an essential difference in relative survival or cure proportion between squamous cell carcinomas and adenocarcinoma was insufficient for interval as well as for overdue cases. Deaths in women with the other histological subtypes were too few to make any meaningful comparisons.
As previously done for screen detected and symptomatic cancers, odds ratios and differences of cure were calculated for interval and overdue cases. Compared with the interval cases, the difference in cure for the overdue cases was $11 \%(95 \%$ confidence interval $5 \%$ to $18 \%$; table 2). In a model also including FIGO stage, the difference in cure for overdue compared with interval cases was statistically non-significant $(5 \%,-2 \%$ to $11 \%)$.

A similar model was constructed for histopathological subtypes, where no difference in cure could be discerned between women with adenocarcinomas and squamous cell carcinomas $(0.1 \%$, $-8 \%$ to $8 \%$ ). When adjusting for FIGO stage (IA, IB, II, and III or higher), this result did not change notably (difference in cure $2 \%,-5 \%$ to $9 \%$ ).

Since age is known to be an important modifier of cervical cancer risk and survival, all analyses were repeated, adjusting for linear effect of age. Differences were negligible (data not shown).

Table $4 \Downarrow$ displays five year relative survival ratios, cure proportions, and differences in cure for women over the age of organised screening ( $\geq 66$ years). In this age group the cure proportion of women with screen detected cancers was higher than for those with symptomatic cancers (difference in cure $36 \%, 95 \%$ confidence interval $11 \%$ to $80 \%$ ), whereas this was not the case for interval cases compared with overdue cases $(14 \%,-7 \%$ to $35 \%)$.

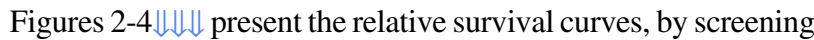
history and mode of detection, histological type, and FIGO stage. Women with screen detected cancer had excellent relative survival independent of previous screening history. Women with symptomatic interval cancer had a better relative survival at all times during follow-up than women who were symptomatic with an overdue or absent screening test (fig 2). Relative survival did not differ between histological types, except for small cell neuroendocrine and undifferentiated cancers (fig 3). FIGO stage was a good predictor of prognosis (fig 4).

\section{Discussion}

Women with cervical cancer diagnosed as a result of a smear test (screen detected cancers) have a better prognosis than women whose cancer is detected on the basis of symptoms, and this improvement was not attributable to lead time bias. To a large extent the improved cure was attributed to screen detected cancers being generally found at earlier clinical FIGO stages than symptomatic cancers.

Women with symptomatic cancer who present within the recommended screening interval - that is, symptomatic interval cancers-have better chances of cure than women with symptomatic cancer with an overdue or absent smear test result. If the screening effect on cure proportions had been due to selective detection of harmless cancers, the more aggressive cases would have appeared as symptomatic interval cancers with higher mortality. On the contrary, we found that women with symptomatic cancers have a better prognosis when cervical cancer is diagnosed between screening intervals than when diagnosed in women who are overdue for screening or not screened.

If cancers were screen detected, relative survival and cure proportion was high irrespective of whether women had previously participated in screening, suggesting that determinants of screening attendance have not confounded the effect. 
Feeling healthy ${ }^{22}$ and a lack of confidence in the benefits of screening ${ }^{23} 24$ are barriers to screening attendance for some women, but our data imply that all women (regardless of previous participation) can be advised that screening will increase the likelihood of cure in case an invasive cancer is detected.

More than three quarters of women who died from cervical cancer had no smear test taken within the recommended screening intervals, implying that the recommended intervals are adequate and that further reduction of incidence and mortality in cervical cancer should focus on reaching women who have not attended screening.

\section{Down-staging}

In women with screen detected cancer down-staging explained a large portion of the improved cure but not the whole difference, compared with women who had symptomatic cancer. A plausible reason could be that our categorisation of FIGO clinical staging of the advanced cancers was too crude to effectively capture the whole effect of early detection by screening. Down-staging does explain the difference in cure between women with interval cancers compared with those who are overdue for screening or have not been screened.

\section{Age}

Half of the women who died from cervical cancer within five years of diagnosis were over the recommended age for screening. As few older women who continued screening died from cervical cancer, half of the cervical cancer mortality was in women with cancers diagnosed beyond screening ages and who had not had a screening test for more than five years. Lethal cervical cancers in young women before screening ages are rare. ${ }^{25}$ No such cases occurred in Sweden during the three years studied. The mortality in patients younger than 30 years was so low we were not able to study the cure proportion separately.

\section{Histopathological type}

Our results showed that the cure proportion for women with adenocarcinomas was similar to that of women with squamous carcinoma, also when controlling for FIGO stage, and that the relative survival of women with adenosquamous carcinoma did not differ from these subtypes. Only women with the poorly differentiated, small cell or neuroendocrine carcinomas had a worse relative survival than women with the other histopathological types.

\section{Abnormal smears}

Women with interval cancers and an abnormal smear test result during the past six years had a non-significantly higher cure proportion than women with only a normal smear test result. If this difference is real, the reason might be that women with abnormal smear test results are followed up to a greater extent than women with normal smear test results. ${ }^{26}$

\section{Other studies}

Survival studies have been carried out in other organised programmes but most have either not distinguished between microinvasive and higher stages ${ }^{3}$ or not considered the influence of opportunistic smear tests in the same population. ${ }^{27-29}$ A recent Italian study ${ }^{30}$ included opportunistic screening. However, no previous study has considered the possible influence of lead time bias or the use of cure proportions to avoid this bias.

\section{Strengths and limitations of the study}

Our audit was designed to eliminate several biases such as those related to selection, testing, and recall ${ }^{131}$ through prospective follow up of all the cases in the nationwide Swedish audit, utilising screening histories from comprehensive cytology registers. $^{132}$

We have shown that cervical screening not only reduces the risk for invasive cervical cancer ${ }^{1}$ but is also associated with improved relative survival and cure. When evaluating screening for cancer it has to be excluded if apparent improvements are due to lead time bias, length bias, overdiagnosis, or confounding. ${ }^{89}$ A possible explanation for a seemingly better relative survival is lead time bias-that is, when detection at an early stage adds time to follow-up but does not alter the course of the disease and does not prolong life. This can be a major confounder in the evaluation of cancer screening. ${ }^{8}$ The cure proportion is a measure independent of lead time bias ${ }^{11}$ and we found significantly higher cure proportions for women with screen detected cancers than for those with symptomatic cancers as well as higher cure proportions for women with symptomatic interval cancers compared with symptomatic overdue cancers.

The possibility of length time bias also has to be considered. If screening picks up small indolent carcinomas but misses a significant proportion of the rapidly growing aggressive tumours, the aggressive tumours would appear in women as symptomatic interval cancers with higher mortality. ${ }^{28} 2933$ However, the relative survival for women with symptomatic interval cancers was better at all times during follow-up than for women with symptomatic cancers and an overdue or absent screening test, and they also had a significantly higher cure proportion.

One possible explanation for the better cure of women with screen detected cancers compared with symptomatic cancers is confounding by "healthy volunteer bias"- that people who participate in screening generally could be more healthy than non-participants. Since most of the female population participate according to recommendations, ${ }^{35}$ non-participants could be considered as "unhealthy abstainers" who theoretically could have a poor prognosis, irrespective of screening. Studies have shown socioeconomic, cultural, and educational differences between participants and non-participants to cervical screening, but less so in countries with nationwide population based programmes. ${ }^{36-38}$ In our study the women with cancers detected by screening had an equally excellent relative survival irrespective of whether or not they had a previous screening test taken within the recommended time, suggesting that determinants of screening attendance were not confounders of the effect. In addition, all Swedish residents are covered by a common health insurance and have access to the same cancer treatment centres. Therefore, a healthy volunteer bias or health selection does not seem to explain our findings, although an effect of confounding cannot be ruled out.

Our cohort comprised all women with cervical cancer in Sweden during three years, classified by age, clinically relevant FIGO stage, and histopathological type, factors individually related to screening history and to the mode of detection based on nationwide databases. All the women in this audit have been followed prospectively in population based registries and all smear tests, also outside the screening programme, are included in the database. To our knowledge the present study is the first to estimate cure proportion after cervical cancer.

One limitation of cure models is that they estimate a cure proportion even when statistical cure is not reached. We have graphically assessed the appropriateness of assuming statistical cure and compared estimated survival from cure models with 
standard relative survival estimates. In the cases where cure was questionable we have chosen not to present results from the cure models. In addition we investigated relative survival by age group using Finnish and Swedish cancer registry data to assess whether a plateau in the relative survival function was observed. If excess mortality occurred after 10 years then the models would be estimating something close to 10 year relative survival rather than the cure proportion. The definition of screen detected and symptomatic cancer is based on interpretation of timing of smear tests in relation to diagnosis of cancer and it is possible that a small number of women with symptomatic cancer and slow investigations could have been classified as having screen detected cancers.

\section{Conclusions}

Detection of invasive cancer by cervical screening implies a favourable prognosis compared with cancer being detected on the basis of symptoms. The effect was stronger than what is reflected in down-staging and was not attributable to lead time bias. Also, women with symptomatic interval cancers had a better prognosis than women with symptomatic cancers who did not have a smear test within the recommended screening interval. The effect on cervical cancer cure should be included when evaluating cervical screening programmes.

Contributors: BA, PS, ST, JD, and BS conceived the audit. BA, PS, TM-LA, PCL, and JD conceived this analysis. BA, LS, LK, ST, and PS collected and standardised the audit database. WR reviewed the diagnostic histopathology specimens of all cancer cases. TM-LA, PCL, and PS did the statistical analyses and drafted the statistical methods section. BA drafted the manuscript with PS and JD. All authors actively participated in the discussion and approved the final version. PS is guarantor.

Funding: This work was supported by grants from the Swedish Cancer Society (02-6988 and 2010/900), the Swedish Foundation for Strategic Research (KF 10-0046), Gävle Cancer Fund (2009-09-17), and the Centre for Research and Development, Uppsala University/County Council of Gävleborg, Sweden (CFUG-82261). The corresponding author had full access to all the data in the study and had the full responsibility to submit the report for publication. The study was conducted and analysed independently from its funders.

Competing interests: All authors have completed the ICMJE uniform disclosure form at www.icmje.org/coi_disclosure.pdf (available on request from the corresponding author) and declare: no support from any organisation for the submitted work; no financial relationships with any organisations that might have an interest in the submitted work in the previous three years; and no other relationships or activities that could appear to have influenced the submitted work.

Ethical approval: This study was approved by the ethical review boards in Uppsala, Stockholm, Umeå, Gothenburg, and Lund and the joint board of Örebro and Linköping, Sweden (FEK Ups 01-322 and EPN 2008/185). The ethical review boards determined that informed consent from participating women was not required.

Data sharing: The analysis dataset for this study is available from the corresponding author at bengt.andrae@ki.se.

Andrae B, Kemetli L, Sparen P, Silfverdal L, Strander B, Ryd W, et al.

Screening-preventable cervical cancer risks: evidence from a nationwide audit in Sweden. J Natl Cancer Inst 2008:100:622-9.

2 Sasieni $P$, Castanon A, Cuzick J. Effectiveness of cervical screening with age: population based case-control study of prospectively recorded data. BMJ 2009;339:b2968.

3 Van der Aa MA, Schutter EM, Looijen-Salamon M, Martens JE, Siesling S. Differences in screening history, tumour characteristics and survival between women with screen-detected versus not screen-detected cervical cancer in the east of the Netherlands, 1992-2001. Eur J Obstet Gynecol Reprod Biol 2008;139:204-9.
4 Djulbegovic M, Beyth RJ, Neuberger MM, Stoffs TL, Vieweg J, Djulbegovic B, et al. Screening for prostate cancer: systematic review and meta-analysis of randomised controlled trials. BMJ 2010;341:c4543.

5 Sandblom G, Varenhorst E, Rosell J, Lofman O, Carlsson P. Randomised prostate cancer screening trial: 20 year follow-up. BMJ 2011;342:d1539.

6 Buys SS, Partridge E, Black A, Johnson CC, Lamerato L, Isaacs C, et al. Effect of screening on ovarian cancer mortality: the Prostate, Lung, Colorectal and Ovarian (PLCO) Cancer Screening Randomized Controlled Trial. JAMA 2011:305:2295-303.

7 Grimes DA, Schulz KF. Uses and abuses of screening tests. Lancet 2002;359:881-4.

Kramer BS, Croswell JM. Cancer screening: the clash of science and intuition. Annu Rev Med 2009;60:125-37.

9 Arbyn M, Rebolj M, De Kok IM, Fender M, Becker N, O'Reilly M, et al. The challenges of organising cervical screening programmes in the 15 old member states of the European Union. Eur J Cancer 2009:45:2671-8.

10 De Angelis R, Capocaccia R, Hakulinen T, Soderman B, Verdecchia A. Mixture models for cancer survival analysis: application to population-based data with covariates. Stat Med 1999;18:441-54

11 Lambert PC, Thompson JR, Weston CL, Dickman PW. Estimating and modeling the cure fraction in population-based cancer survival analysis. Biostatistics 2007;8:576-94.

12 Socialstyrelsen. Gynekologisk cellprovskontroll. [Cervical cancer screening.] SoS-rapport 1998:15. National Board of Health and Welfare, 1998.

13 Att förebygga cervixcancer samt vaginal-och vulvacancer. [Prevention of cervical, vaginal and vulvar cancer-guidelines.] ARG rapport Vol 34. Swedish Society for Obstetricians and Gynaecologists, 1997.

14 Cervix cancer prevention. [Cervical cancer prevention, guidelines for the management of CIN.] ARG-rapport Vol 63. Swedish Society of Obstetricians and Gynaecologists, 2010.

15 Arbyn M, Raifu AO, Weiderpass E, Bray F, Anttila A. Trends of cervical cancer mortality in the member states of the European Union. Eur J Cancer 2009;45:2640-8.

16 Kosary C. FIGO stage, histology, histologic grade, age and race as prognostic factors in determining survival of cancers. Semin Surg Oncol 2006;10:31-46.

17 Odicino F, Pecorelli S, Zigliani L, Creasman WT. History of the FIGO cancer staging system. Int J Gynaecol Obstet 2008;101:205-10.

18 Sparen P, Gustafsson L, Friberg LG, Ponten J, Bergstrom R, Adami HO. Improved control of invasive cervical cancer in Sweden over six decades by earlier clinical detection and better treatment. J Clin Oncol 1995;13:715-25.

19 Dickman PW, Adami HO. Interpreting trends in cancer patient survival. J Intern Med 2006;260:103-17.

20 Lambert PC, Dickman PW, Osterlund P, Andersson T, Sankila R, Glimelius B. Temporal trends in the proportion cured for cancer of the colon and rectum: a population-based study using data from the Finnish Cancer Registry. Int J Cancer 2007;121:2052-9.

21 Lambert PC. Modeling of the cure fraction in survival studies. Stata $J$ 2007;7:351-75.

22 Oscarsson MG, Benzein EG, Wijma BE. Reasons for non-attendance at cervical screening as reported by non-attendees in Sweden. J Psychosom Obstet Gynaecol 2008;29:23-31.

23 Blomberg K, Ternestedt BM, Tornberg S, Tishelman C. How do women who choose not to participate in population-based cervical cancer screening reason about their decision? Psychooncology 2008;17:561-9.

24 Waller J, Bartoszek M, Marlow L, Wardle J. Barriers to cervical cancer screening attendance in England: a population-based survey. J Med Screen 2009;16:199-204.

25 Edelstein ZR, Madeleine MM, Hughes JP, Johnson LG, Schwartz SM, Galloway DA, et al. Age of diagnosis of squamous cell cervical carcinoma and early sexual experience. Cancer Epidemiol Biomarkers Prev 2009:18:1070-6.

26 Silfverdal L, Kemetli L, Andrae B, Sparen P, Ryd W, Dillner J, et al. Risk of invasive cervical cancer in relation to management of abnormal Pap smear results. Am J Obstet Gynecol 2009;201:188,e1-7.

27 Nieminen P, Kallio M, Hakama M. The effect of mass screening on incidence and mortality of squamous and adenocarcinoma of cervix uteri. Obstet Gynecol 1995;85:1017-21.

28 Shingleton HM, Bell MC, Fremgen A, Chmiel JS, Russell AH, Jones WB, et al. Is there really a difference in survival of women with squamous cell carcinoma, adenocarcinoma, and adenosquamous cell carcinoma of the cervix? Cancer 1995;76(Suppl 10):1948-55.

29 Welch HG, Black WC. Overdiagnosis in cancer. J Natl Cancer Inst 102:605-13.

30 Zucchetto A, Franceschi S, Clagnan E, Serraino D, Zanier L, Franzo A. Screening history of women with invasive cervical cancer in north-east Italy. Eur J Obstet Gynecol Reprod Biol 2010;152:200-4.

31 Andrae B, Strander B, Silfverdal L, Ryd W, Dillner J, Tornberg S, et al. Benefit of cervical cancer screening in young women-a matter of adherence to the recommended screening interval. Response to Sasieni et al. BMJ 2009;339:b2968.

32 Cuzick J. Routine audit of large-scale cervical cancer screening programs. J Natl Cancer Inst 2008;100:605-6.

33 Hildesheim A, Hadjimichael O, Schwartz PE, Wheeler CM, Barnes W, Lowell DM, et al. Risk factors for rapid-onset cervical cancer. Am J Obstet Gynecol 1999;180:571-7.

34 Kitchener HC. Survival from cancer of the uterine cervix in England and Wales up to 2001. Br J Cancer 2008;99(Suppl 1):S63-4.

35 Swedish cervical cancer screening register. Report on data to 2006. [In Swedish.] 2007. http://ki.se/content/1/c6/05/05/04/Rapport_2007.pdf.

36 Rodvall Y, Kemetli L, Tishelman C, Tornberg S. Factors related to participation in a cervical cancer screening programme in urban Sweden. Eur J Cancer Prev 2005;14:459-66.

37 Azerkan F, Sparen P, Sandin S, Tillgren P, Faxelid E, Zendehdel K. Cervical screening participation and risk among Swedish-born and immigrant women in Sweden. Int J Cancer 2012;130:927-47.

38 Palencia L, Espelt A, Rodriguez-Sanz M, Puigpinos R, Pons-Vigues M, Pasarin MI, et al. Socio-economic inequalities in breast and cervical cancer screening practices in Europe: influence of the type of screening program. Int J Epidemiol 39:757-65.

Accepted: 8 December 2011

\section{Cite this as: BMJ 2012;344:e900}

This is an open-access article distributed under the terms of the Creative Commons Attribution Non-commercial License, which permits use, distribution, and reproduction in any medium, provided the original work is properly cited, the use is non commercial and is otherwise in compliance with the license. See: http://creativecommons.org/licenses/bync/2.0/ and http://creativecommons.org/licenses/by-nc/2.0/legalcode. 


\section{What is already known on this topic}

Women with cervical cancers detected by screening have an improved survival

However, evaluations of the benefit of screening programmes can be distorted by lead time bias

\section{What this study adds}

Cervical cancer screening is associated with improved cure

The effect is not attributable to lead time bias and is larger than what is reflected in earlier stage diagnosis (down-staging)

Evaluations of screening programmes should consider the assessment of cure proportions

\section{Tables}

Table 1| Five year relative survival ratios and cure proportions of cervical cancer for women age 23-65, by mode of detection, clinical stage, and histopathology

\begin{tabular}{|c|c|c|c|c|c|c|c|c|c|c|c|}
\hline \multirow[b]{2}{*}{ Variables } & \multicolumn{5}{|c|}{ Screen detected cancers } & \multicolumn{5}{|c|}{ Symptomatic cancers } & \multirow{2}{*}{$\begin{array}{c}\text { Difference } \\
\text { in cure } \\
(95 \% \mathrm{Cl})\end{array}$} \\
\hline & $\begin{array}{l}\text { No of } \\
\text { cases }\end{array}$ & $\begin{array}{c}\text { Cancer } \\
\text { specific } \\
\text { death at } \\
\text { five } \\
\text { years }\end{array}$ & $\begin{array}{l}\text { Deaths } \\
\text { during } \\
\text { observation } \\
\text { period }\end{array}$ & $\begin{array}{l}5 \text { year } \\
\text { relative } \\
\text { survival } \\
(95 \% \mathrm{Cl})\end{array}$ & $\begin{array}{l}\text { Cure } \\
\text { proportion } \\
(95 \% \mathrm{Cl})\end{array}$ & $\begin{array}{l}\text { No of } \\
\text { cases }\end{array}$ & $\begin{array}{c}\text { Cancer } \\
\text { specific } \\
\text { death at } \\
\text { five } \\
\text { years }\end{array}$ & $\begin{array}{l}\text { Deaths } \\
\text { during } \\
\text { observation } \\
\text { period }\end{array}$ & $\begin{array}{l}5 \text { year } \\
\text { relative } \\
\text { survival } \\
(95 \% \mathrm{Cl})\end{array}$ & $\begin{array}{c}\text { Cure } \\
\text { proportion } \\
(95 \% \mathrm{Cl})\end{array}$ & \\
\hline All cases & 273 & 11 & 22 & 95 (92 to 97$)$ & $\begin{array}{c}92 \text { (75 to } \\
98)\end{array}$ & 567 & 166 & 199 & 69 (65 to 73) & 66 (62 to 70$)$ & $\begin{array}{c}26(15 \text { to } \\
36)\end{array}$ \\
\hline \multicolumn{12}{|l|}{$\begin{array}{l}\text { Latest screening } \\
\text { interval: }\end{array}$} \\
\hline Interval cases & 153 & 6 & 15 & 95 (90 to 98 ) & $-^{*}$ & 256 & 65 & 72 & 75 (69 to 80$)$ & 74 (68 to 79$)$ & $\begin{array}{c}14(6 \text { to } \\
23) \dagger\end{array}$ \\
\hline Overdue cases & 120 & 5 & 7 & 96 (90 to 98$)$ & $\begin{array}{c}95 \text { (87 to } \\
98)\end{array}$ & 311 & 101 & 127 & 65 (60 to 70$)$ & 60 (53 to 66$)$ & \\
\hline \multicolumn{12}{|l|}{ FIGO stage: } \\
\hline $\begin{array}{l}\text { IA } \\
\text { (microinvasive) }\end{array}$ & 137 & 2 & 5 & $\begin{array}{c}98 \text { (93 to } \\
100)\end{array}$ & $\begin{array}{c}98 \text { (96 to } \\
99)\end{array}$ & 99 & 5 & 7 & 94 (86 to 97 ) & 94 (88 to 97 ) & 4 (3 to 7$)$ \\
\hline IB (localised) & 117 & 3 & 10 & $\begin{array}{c}97 \text { (92 to } \\
100)\end{array}$ & $\begin{array}{c}91 \text { (83 to } \\
95)\end{array}$ & 280 & 51 & 71 & 81 (76 to 85$)$ & 75 (68 to 81$)$ & 16 (8 to 23$)$ \\
\hline $\begin{array}{l}\text { Il or higher } \\
\text { (advanced) }\end{array}$ & 19 & 6 & 7 & 64 (38 to 81$)$ & $\begin{array}{c}65 \text { (48 to } \\
80)\end{array}$ & 188 & 110 & 121 & 40 (32 to 47$)$ & 37 (30 to 44$)$ & $\begin{array}{c}29(13 \text { to } \\
45)\end{array}$ \\
\hline \multicolumn{12}{|l|}{ Histopathology: } \\
\hline $\begin{array}{l}\text { Squamous cell } \\
\text { carcinoma }\end{array}$ & 203 & 6 & 14 & 97 (93 to 99) & $\begin{array}{c}93 \text { (86 to } \\
96)\end{array}$ & 412 & 115 & 143 & 71 (66 to 75$)$ & 67 (61 to 72$)$ & $\begin{array}{c}26 \text { (20 to } \\
33)\end{array}$ \\
\hline Adenocarcinoma & 65 & 5 & 8 & 90 (79 to 96$)$ & $\begin{array}{c}93 \text { (86 to } \\
96)\end{array}$ & 121 & 37 & 41 & 68 (59 to 76$)$ & 66 (57 to 74$)$ & $\begin{array}{c}27 \text { (18 to } \\
35)\end{array}$ \\
\hline $\begin{array}{l}\text { Adenosquamous } \\
\text { carcinoma }\end{array}$ & 3 & 0 & 0 & $>100$ & - & 18 & 5 & 5 & 73 (46 to 88 ) & - & - \\
\hline $\begin{array}{l}\text { Small cell } \\
\text { carcinoma }\end{array}$ & 2 & 0 & 0 & $>100$ & - & 16 & 9 & 10 & 44 (20 to 66$)$ & - & - \\
\hline
\end{tabular}

*Estimate could not be calculated reliably owing to poor fitting cure model.

tInterval and overdue symptomatic cancer cases compared. 
Table 2/ Odds ratios and differences in cure from cervical cancer on women aged 23-65, by mode of detection and previous screening history

\begin{tabular}{|c|c|c|c|c|}
\hline \multirow[b]{2}{*}{ Variables } & \multicolumn{2}{|c|}{ Odds ratio $(95 \% \mathrm{Cl})$} & \multicolumn{2}{|c|}{ Difference in cure $(95 \% \mathrm{Cl})$} \\
\hline & Unadjusted & Adjusted for FIGO stage & Unadjusted & Adjusted for FIGO stage* \\
\hline \multicolumn{5}{|l|}{ Mode of detection: } \\
\hline Screen detected (reference) & 1.00 & 1.00 & \multirow[t]{2}{*}{26 (15 to 36$)$} & \multirow[t]{2}{*}{15 (7 to 22$)$} \\
\hline Symptomatic & $0.17(0.05$ to 0.65$)$ & $0.31(0.16$ to 0.62$)$ & & \\
\hline \multicolumn{5}{|l|}{ Previous screening history: } \\
\hline Screened (reference) & $1 \cdot 00$ & $1 \cdot 00$ & \multirow[t]{2}{*}{11 (5 to 18$)$} & \multirow[t]{2}{*}{$5(-2$ to 11$)$} \\
\hline Screening overdue or no smear & 0.55 (0.38 to 0.79$)$ & $0.72(0.46$ to 1.12$)$ & & \\
\hline
\end{tabular}


Table 3| Five year relative survival ratios and cure proportions of cervical cancer for women age 23-65 by previous screening history, clinical stage, and histopathology

\begin{tabular}{|c|c|c|c|c|c|c|c|c|c|c|c|}
\hline \multirow[b]{2}{*}{ Variables } & \multicolumn{5}{|c|}{ Screened within recommended interval } & \multicolumn{5}{|c|}{ Screening overdue or no smear test } & \multirow{2}{*}{$\begin{array}{c}\text { Difference } \\
\text { in cure } \\
(95 \% \mathrm{Cl})\end{array}$} \\
\hline & $\begin{array}{l}\text { No of } \\
\text { cases }\end{array}$ & $\begin{array}{c}\text { Cancer } \\
\text { specific } \\
\text { death at } \\
\text { five } \\
\text { years }\end{array}$ & $\begin{array}{c}\text { Deaths } \\
\text { during } \\
\text { observation } \\
\text { period }\end{array}$ & $\begin{array}{c}5 \text { year } \\
\text { relative } \\
\text { survival }(95 \% \\
\text { Cl) }\end{array}$ & $\begin{array}{l}\text { Cure } \\
\text { proportion } \\
(95 \% \mathrm{Cl})\end{array}$ & $\begin{array}{l}\text { No of } \\
\text { cases }\end{array}$ & $\begin{array}{l}\text { Cancer } \\
\text { specific } \\
\text { death at } \\
\text { five } \\
\text { years }\end{array}$ & $\begin{array}{c}\text { Deaths } \\
\text { during } \\
\text { observation } \\
\text { period }\end{array}$ & $\begin{array}{l}5 \text { year } \\
\text { relative } \\
\text { survival } \\
(95 \% \mathrm{Cl})\end{array}$ & $\begin{array}{c}\text { Cure } \\
\text { proportion } \\
(95 \% \mathrm{Cl})\end{array}$ & \\
\hline All cases & 409 & 71 & 87 & 82 (78 to 86$)$ & 81 (76 to 85$)$ & 431 & 106 & 134 & 74 (69 to 78$)$ & $\begin{array}{c}70(65 \text { to } \\
74)\end{array}$ & $11(5$ to 18$)$ \\
\hline \multicolumn{12}{|l|}{$\begin{array}{l}\text { Latest screening } \\
\text { interval: }\end{array}$} \\
\hline $\begin{array}{l}\text { Normal smear } \\
\text { test result }\end{array}$ & 278 & 57 & 66 & 80 (74 to 84$)$ & 78 (72 to 83$)$ & - & - & - & - & - & $\begin{array}{c}8(-0.4 \text { to } \\
17)\end{array}$ \\
\hline $\begin{array}{l}\text { Abnormal smear } \\
\text { test result }\end{array}$ & 131 & 14 & 21 & 88 (81 to 93$)$ & 86 (78 to 92$)$ & - & - & - & - & - & \\
\hline \multicolumn{12}{|l|}{ FIGO stage: } \\
\hline $\begin{array}{l}\text { IA } \\
\text { (microinvasive) }\end{array}$ & 126 & 2 & 6 & 97 (92 to 99$)$ & 97 (94 to 99$)$ & 110 & 5 & 6 & 95 (89 to 98$)$ & $\begin{array}{c}96 \text { (91 to } \\
98)\end{array}$ & $1(-0.4$ to 3$)$ \\
\hline IB (localised) & 211 & 31 & 42 & 86 (80 to 90$)$ & 82 (75 to 87 ) & 186 & 23 & 39 & 86 (80 to 90$)$ & $\begin{array}{c}74(63 \text { to } \\
83)^{\star}\end{array}$ & $7(-1$ to 15$)$ \\
\hline $\begin{array}{l}\text { Il or higher } \\
\text { (advanced) }\end{array}$ & 72 & 38 & 39 & 47 (35 to 58$)$ & 46 (36 to 56 ) & 135 & 78 & 89 & 39 (31 to 47$)$ & $\begin{array}{c}35 \text { (28 to } \\
44)\end{array}$ & $\begin{array}{c}10(-0.6 \text { to } \\
21)\end{array}$ \\
\hline \multicolumn{12}{|l|}{ Histopathology: } \\
\hline $\begin{array}{l}\text { Squamous cell } \\
\text { carcinoma }\end{array}$ & 272 & 37 & 50 & 86 (81 to 90$)$ & 81 (75 to 86 ) & 343 & 84 & 107 & 74 (69 to 78 ) & $\begin{array}{c}71(65 \text { to } \\
76)\end{array}$ & 10 (3 to 17$)$ \\
\hline Adenocarcinoma & 119 & 28 & 31 & 76 (67 to 83 ) & $\begin{array}{c}79(72 \text { to } \\
85)^{\star}\end{array}$ & 67 & 14 & 18 & 75 (63 to 84$)$ & $\begin{array}{c}69(59 \text { to } \\
77)^{*}\end{array}$ & 10 (3 to 18$)$ \\
\hline $\begin{array}{l}\text { Adenosquamous } \\
\text { carcinoma }\end{array}$ & 11 & 1 & 1 & 92 (52 to 100$)$ & - & 10 & 4 & 4 & 60 (25 to 83 ) & - & \\
\hline $\begin{array}{l}\text { Small cell } \\
\text { carcinoma }\end{array}$ & 7 & 5 & 5 & 29 (4 to 63$)$ & - & 11 & 4 & 5 & 64 (30 to 85 ) & - & \\
\hline
\end{tabular}


Table 4| Five year relative survival ratios and cure proportions of cervical cancer for women age 66 or older by mode of detection and previous screening history

\begin{tabular}{|c|c|c|c|c|c|c|}
\hline Variables & No of cases & $\begin{array}{l}\text { Cancer specific } \\
\text { death at five years }\end{array}$ & $\begin{array}{l}\text { Deaths during } \\
\text { observation period }\end{array}$ & $\begin{array}{l}5 \text { year relative survival } \\
\qquad(95 \% \mathrm{Cl})\end{array}$ & $\begin{array}{l}\text { Cure proportion }(95 \% \\
\qquad \mathrm{Cl})\end{array}$ & $\begin{array}{l}\text { Difference in cure } \\
\qquad(95 \% \mathrm{Cl})\end{array}$ \\
\hline \multicolumn{7}{|l|}{ Mode of detection: } \\
\hline Screen detected cancers & 23 & 5 & 11 & 77 (48 to 97$)$ & 76 (46 to 92$)$ & \multirow[t]{2}{*}{36 (11 to 80$)$} \\
\hline Symptomatic cancers & 367 & 191 & 278 & 44 (38 to 50$)$ & 40 (33 to 47 ) & \\
\hline \multicolumn{7}{|l|}{ Screening history: } \\
\hline $\begin{array}{l}\text { Screened within recommended } \\
\text { interval }\end{array}$ & 32 & 12 & 19 & 56 (35 to 74$)$ & 54 (35 to 72$)$ & \multirow[t]{2}{*}{$14(-7$ to 35$)$} \\
\hline $\begin{array}{l}\text { Screening overdue or no } \\
\text { smear test }\end{array}$ & 358 & 184 & 270 & 45 (38 to 51$)$ & 40 (32 to 48 ) & \\
\hline
\end{tabular}




\section{Figures}

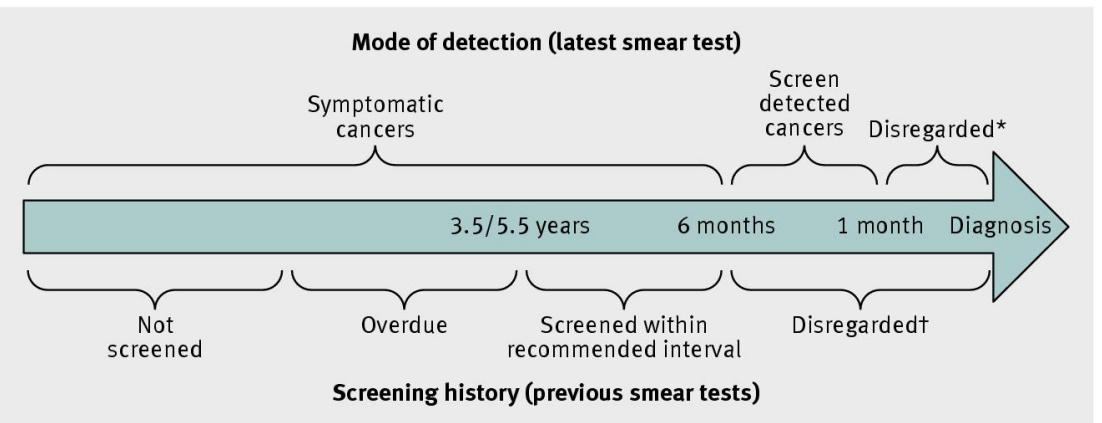

Fig 1 Definition of mode of detection and screening history based on time since latest smear test. ${ }^{*}$ Result of smear tests taken without clinical suspicion do not lead to diagnosis of invasive cancer in less than one month. †Smear tests taken less than six months before diagnosis cannot have prevented invasive cancer but are considered, after referral and biopsy, to lead to diagnosis of a prevalent cancer

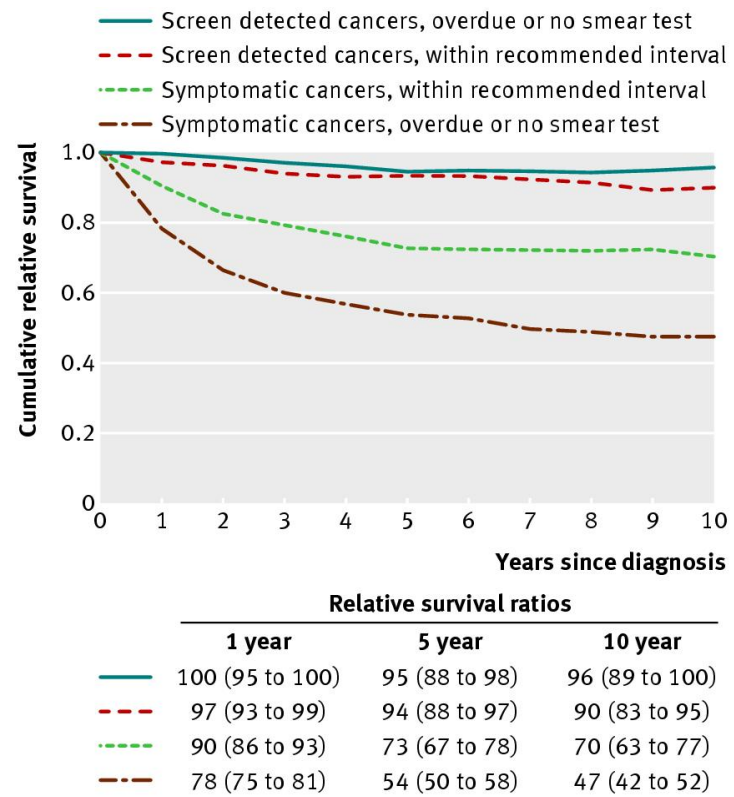

Fig 2 Relative survival ratios of cervical cancer (all histological types) for women of all ages, by screening history and mode of detection 


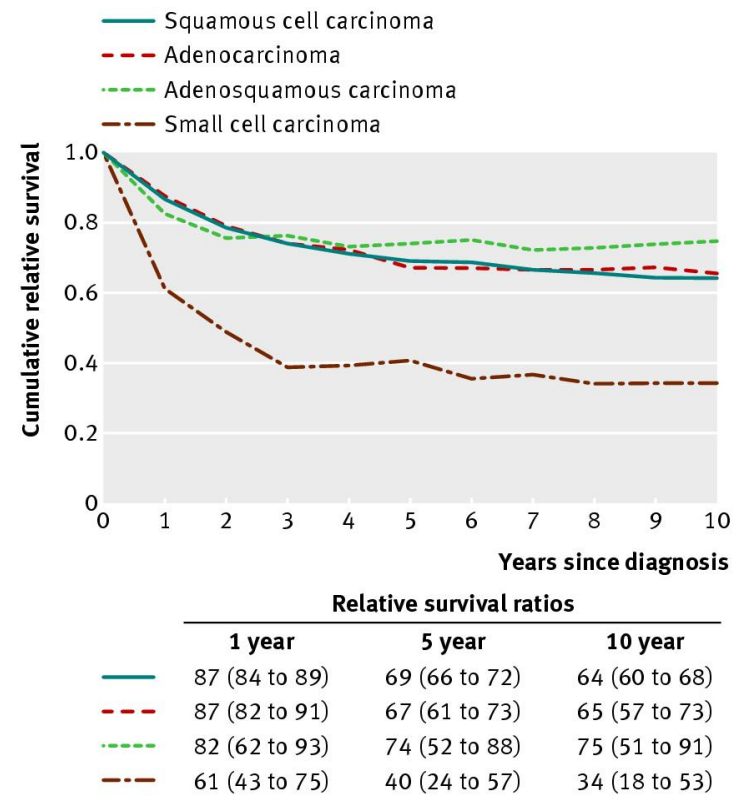

Fig 3 Relative survival ratios of cervical cancer for women of all ages, by histological type

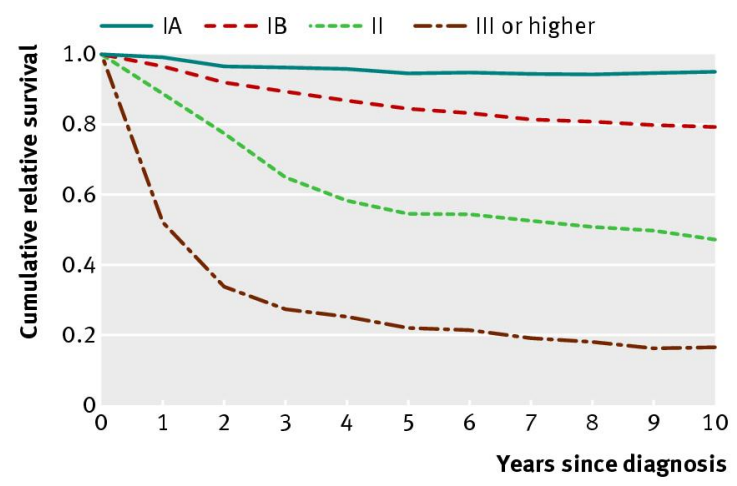

\begin{tabular}{cccc} 
& \multicolumn{3}{c}{ Relative survival ratios } \\
\cline { 2 - 4 } & 1 year & $\mathbf{5}$ year & 10 year \\
- & $99(97$ to 100$)$ & $95(91$ to 97$)$ & $95(91$ to 98$)$ \\
--- & $97(95$ to 98$)$ & $85(81$ to 88$)$ & $80(74$ to 84$)$ \\
--- & $89(83$ to 93$)$ & $54(47$ to 62$)$ & $47(36$ to 59$)$ \\
--- & $52(46$ to 58$)$ & $22(17$ to 28$)$ & $17(12$ to 22$)$
\end{tabular}

Fig 4 Relative survival ratios of cervical cancer (all histological types) for women of all ages, by FIGO stage 